THE GREAT TEXAS WIND RUSH

NUMBER SIX

Peter T. Flawn Series in Natural Resources 


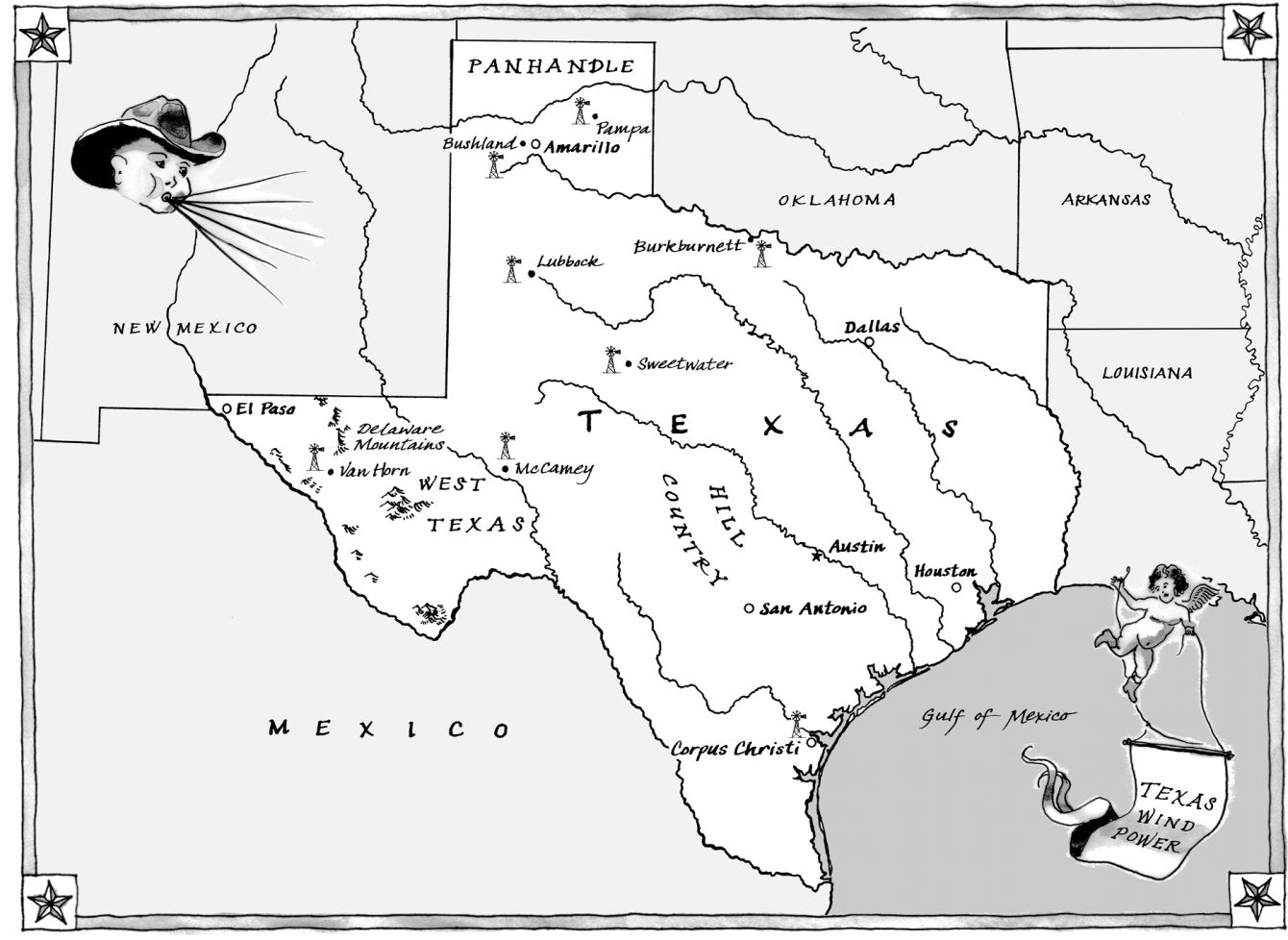


How George Bush, Ann Richards, and a Bunch of Tinkerers

Helped the Oil and Gas State

Win the Race to Wind Power

\section{T直直些 G G}

BY KATE GALBRAITH

AND ASHER PRICE

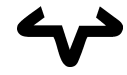

University of Texas Press 
The Peter T. Flawn Series in Natural Resource Management and Conservation is supported by a grant from the National Endowment for the Humanities and by gifts from various individual donors.

Copyright (C) 2013 by the University of Texas Press All rights reserved Printed in the United States of America First edition, 2013

Map by Molly O’Halloran, Inc.

Requests for permission to reproduce material from this work should be sent to:

Permissions

University of Texas Press

P.O. Box 7819

Austin, TX 78713-7819

http://utpress.utexas.edu/about/book-permissions

(2) The paper used in this book meets the minimum requirements of ANSI/NISO Z39.48-1992 (R1997) (Permanence of Paper).

Library of Congress Cataloging-in-Publication Data Galbraith, Kate (Catherine)

The great Texas wind rush : how George Bush, Ann Richards, and a bunch of tinkerers helped the oil and gas state win the race to wind power / by Kate Galbraith and Asher Price. - 1st ed.

p. $\quad$ cm. - (Peter T. Flawn series in natural resources ; no. 6 )

Includes bibliographical references and index. ISBN 978-0-292-73583-5 (cloth : alk. paper)

1. Wind power-Government policy-Texas. 2. Renewable energy sources-Texas. I. Price, Asher. II. Title.

TJ820.G35 2013

$333.9^{\prime} 209764-\mathrm{dc} 23$

2012044363

doi:10.7560/735835 